\title{
The fallacy of the social State in Colombia*
}

\author{
La falacia del Estado \\ social en Colombia
}

\section{René Moreno Alfonso**}

Artículo de reflexión

Fecha de Recepción: 10 de enero de 2021

Fecha de Aceptación: 26 de febrero de 2021

\section{Para citar este artículo:}

Moreno Alfonso, R. (2021). The fallacy of the social State in Colombia. Revista Análisis JurídicoPolítico, 3(5), 59-94. https://doi.org/10.22490/26655489.4585

\section{Abstract}

This document carries out a normative and jurisprudential analysis on the model of the Social State of Law and Social Rights introduced by the 1991 Constitution, to validate its development. The main goal is to contrast the normative design with the reality of Colombian society to consider whether the social purposes of the state are met or if, on the contrary, the Social State of Law is a legal

\footnotetext{
* Critical review about the analysis of the Social State of Law in Colombia, in 30 years of the Political Constitution of 1991.

** Lawyer from the Universidad Libre de Colombia and sociologist from the Universidad Nacional de Colombia. President of the Colombian Association of Constitutional Procedural Law (ACDPC) and general secretary of the World Association of Constitutional Justice (AMJC). Member of the Colegio de Abogados Procesalistas Latinoamericanos, research professor at the Corporación Universitaria Republicana and postgraduate professor at the Universidad Libre de Colombia. ORCID: orcid.org/0000-0001-8383-0998. E-mail: rmoreno@urepublicana.edu.co
} 
discourse and not a reality. To achieve such goal, the emergence and evolution of the concept of Social State of Law and its application in Colombian constitutionalism are taken into account; The study of social rights is carried out in conceptual and quantitative terms with satisfaction/deficiency indicators to identify the effectiveness degree those rights that allow the progress or setbacks of the Social State of Law to be concluded. The contrast among constitutional norms, jurisprudential rules and empirical data on the effectiveness of social rights lead us to the conclusion that in 30 years of legitimacy of the Colombian Constitution 1991-2021, the Social Rule of Law in our country is a fallacy that needs to be transformed into reality by social actors to undertake the programmatic content of the constitution. To fulfill social needs, there are legalpolitical instruments such as the National Development Plan and the Multi-Year Budgets, which meet public policy to procure the improvement and quality of life of Colombians and show that the Social State of Law is not a simple constitutional formula.

Keywords: Social Law; National Development Plan; Public politics; General Budget of the Nation.

\section{Resumen}

En el presente escrito se realiza un análisis normativo y jurisprudencial sobre el modelo de Estado social de derecho y los derechos sociales introducidos por la Constitución de 1991, para verificar su materialización. Tiene como objetivo confrontar el diseño normativo con la realidad de la sociedad colombiana para examinar si se cumplen con los fines sociales del Estado o si, por el contrario, el Estado social de derecho es un discurso jurídico y no una realidad. Para lograr tal objetivo se tiene en cuenta el surgimiento y evolución del concepto Estado social de derecho y su aplicación en el constitucionalismo colombiano. Por su parte, el estudio de los derechos sociales se efectúa en términos conceptuales y cuantitativos, con indicadores de satisfacción o deficiencia, para determinar el grado de eficacia de estos derechos y concluir los avances o retrocesos del Estado social de derecho. La confrontación entre las normas constitucionales, las reglas ju- 
risprudenciales y los datos empíricos sobre la efectividad de los derechos sociales permiten concluir que en 30 años de vigencia de la Constitución Colombiana (1991-2021), el Estado social de derecho es una falacia que requiere ser transformada en realidad por los actores sociales, con el fin de materializar el contenido programático de la Constitución. Para satisfacer las necesidades sociales existen instrumentos jurídicos y políticos, como el Plan Nacional de Desarrollo (PND) y los presupuestos plurianuales, que responden a una política pública para obtener el mejoramiento de la calidad de vida de los colombianos y ponen de manifiesto que el Estado social de derecho no es una simple fórmula constitucional.

Palabras clave: derecho social, Plan Nacional de Desarrollo, política pública, presupuesto general de la nación.

\section{INTRODUCTION}

Upon the thirtieth anniversary of the approval and issuance of Colombia's political letter of 1991, a balance was made on the expectations of change and transformation of Colombian society in the three decades of legitimacy of the Social Rule of Law (from now on SRL). In the philosophical, political and legal dimensions, one of the innovations in the 1991 Constitution was the adoption of an SRL design. In the philosophical field, this is a constitutional value; in the political field it is a collective construction; and at the legal level it is binding on the bodies of power and the associates.

The 1991 constitutional text adopted the following legal-political organization model:

Colombia is a social state under the rule of law, organized in the form of a unitary republic, decentralized, with autonomy of its territorial units, democratic, participatory, and pluralistic, based on the respect of human dignity, the work and solidarity of the individuals who belong to it, and the prevalence of the general interest. (Political Constitution of Colombia, 1991) 
From the previous set of qualities or characteristics of the constitutional design of the Colombian State - and because of its collective importance - we will heed the social component or adjective of the Social State.

The social State model is in accordance with the essential purposes of the State of:

[...] The essential purposes of the State are to serve the community, promote overall prosperity, and ensure the effective exercise of the principles, rights, and duties enshrined in the Constitution; and to facilitate participation by all people in decisions that affect them and in the economic, political, administrative, and cultural life of the Nation. Government authorities are appointed to protect the life, honor, property, beliefs and other rights and freedoms of residents of Colombia and to ensure fulfillment of the social duties of the State and of individuals. (Political Constitution of Colombia, 1991)

To fulfill the social purposes of the State, the appropriation bill established the duty to include a component called social public spending. In its territorial distribution, such spending must take into account the number of people with unsatisfied basic needs, as well as the population and fiscal and administrative efficiency (Political Constitution of Colombia, 1991).

Within the social purposes of the State, the duty is imposed to ensure the provision of public services efficiently to all the inhabitants of the national territory, as well as the general well-being and the improvement of the quality of life of the population. This through solving the unmet needs in health, education, environmental sanitation and drinking water. In regulatory terms, it is a State that has to direct its activity not only to the protection or guarantee of individual rights, but to embody social rights for the construction of a more balanced and fair society in the satisfaction of needs.

The task at hand is not one of institutional design, but of the fulfillment of constitutional norms by the holders of power during 
these three decades of legitimacy of the Social State. To analyze the application of the social component of the Colombian State, we will consider the variables health, education, drinking water, economic growth, unemployment, and poverty. This, with the purpose of finding the advances or liabilities of the Social State in Colombia.

The methodology to achieve this purpose is to consider, from the qualitative point of view, the main social rights. Likewise, in order to understand their content and assess their effectiveness, we followed indicators to identify the degree of embodiment of the Social Rule of Law in our country in the timeframe 1991-2021.

\section{Development of the Social State in Colombia}

In the historical development of Colombian constitutionalism, the social component within the purposes of the State does not arise with the 1991 Constitution. On the contrary, it is the product of the socio-political evolution of Colombian prevailing circumstances, which concludes in a first phase with the consolidated legislation of qualifying the State with the adjective of social in the 1991 political charter. In a second phase, which is the one that we propose with this writing, the scope and achievements of this SRL model are verified.

The foundation of the Colombian nation-state as a political and unitary organization has as its starting point the political Constitution of 1886. This formulated a model of a gendarme or police state that was the guarantor only of individual rights in the face of the call for help from its associates. This constitution is foundational, because it raised unity in the following aspects: 1) population; 2) territory; 3) political power; 4) currency; 5) legislation; and 6) public force. The previous model of political organization managed to overcome the social, political and legal crisis originated in the Federalist Constitution of 1863.

A great rupture of this model of State occurred thanks to the constitutional reform of 1936, during the government of Alfonso López Pumarejo. This reform was driven by the political proposal called 
Revolution in progress and promoted by the influence of the ideas of the Bolshevik Revolution (1917), the Mexican Constitution (1917), the solidarity doctrines of the Catholic Church and the legal postulates of the French Jurist Leon Duguit (Colombian Constitutional Court, Sentence T-406/92, 1992; Sentence C-295/93, 1993).

The background on the interest that the State had in the problems of society as a whole, refer to the thought of the German Sociologist Lorenz Von Stein; the proposals of Chancellor Otto Von Bismarck; the work of Karl Marx, who sought an egalitarian society that avoided the exploitation of the working class; the postulates of Herman Heller, who spread the idea of the Social State of Law; and Peter Häberle, who considered the Social Rule of Law as a collective conquest of legal science, committed to social justice, and as a general and abstract formula that required political configuration and multiple interpretation (Häberle et ál. 2007).

The social state is related to the welfare state proposed by William Temple, in 1941, under the name Welfare State. At present, the conception of the social state is compatible with the Freiburg school approach, which defends the social market state.

One of the changes introduced by the constitutional reform of 1936 was to add social interest to the guarantee of private property as a reason for preference over private interest. In this concept, it was indicated that there could be expropriation for reasons of public utility or social interest, when the text of the Constitution of 1886 only allowed expropriation for serious reasons of public utility.

This reform (1936) allowed the expropriation by means of a judicial sentence and prior compensation, which constitutes a forced alienation and meets the following requirements: 1 ) that there is a reason for public utility or social interest defined by the legislator; 2) that the alienation be decreed by court order; and 3) that the value of the property is paid to its indemnified owner before the expropriation is verified. In these cases it cannot be affirmed that judicially there is a true expropriation, since the owner is not deprived of his property, because there is a change in the form of property through forced alienation. 
Another aspect that highlights the constitutional reform is that "property is a social function that implies obligations" (Legislative Act 1,1936 ). Here the guarantee of private property coexists as an individual right -with its social function- which implies obligations; that is, property as an individual right limited in its use by social interests (Legislative Act 1, 1936).

This conception of property was inspired by the Duguit Theory, which taught that:

In any country where individual property is recognized by positive legislation, the owner has, by the very fact of being so, a certain social function to fulfill and the extent of his property right must be determined by law and by jurisprudence that applies it, according to the social function to be met. (Tascón, 1944)

The property right introduced by the 1936 reform presented a contradiction, because it embodied, in turn, an individual subjective right and a content right as a social function. This was resolved by understanding that property, as an individual right to satisfy needs, has a social function that consists of using and disposing of the property in the interest of the community.

The 1991 political charter continued with the guarantee of private property and its social function, which implied obligations as well as limitations, for reasons of public utility or social interest (Political Constitution of Colombia, art. 58, 1991). This qualitative leap from the Constitution of 1886 to that of 1991 in the design of the State - which is no longer only a guarantor of individual rights, but of social interest - allows us to consider whether state actions have fulfilled that role of the Social Rule of Law.

\section{Concept of Social Rule of Law in constitutional JURISPRUDENCE}

The Constitutional Court of Colombia has indicated that the formula of the first article of the Constitution (expanded and supported 
throughout the fundamental text) - according to which Colombia is defined as a Social State of Law - has unprecedented importance in the context of Colombian constitutionalism. The significance of the Court's ruling on the scope of this concept and on its meaning and interpretation makes it possible to relate economic, social and cultural rights with the Social Rule of Law.

The Highest Constitutional Court specified the concept of the Rule of Law in the following terms:

1. The first thing to be noticed is that the term "social", now added to the classic formula of the rule of law, should not be understood as a simple rhetorical catchphrase that provides an elegant touch of philanthropy to the traditional idea of law and of the State. A long history of institutional transformations in the main constitutional democracies of the world is present to testify to the importance of this concept.

2. The incidence of the social rule of law in the sociopolitical organization can be described schematically from two points of view: quantitative and qualitative. The former is usually dealt with under the theme of the welfare state (welfare State, stato di benessere, L'État Providence) and the latter under the theme of the democratic constitutional state. The delimitation between both concepts is not sharp; each of them refers to a specific aspect of the same issue. Their complementarity is evident. (Colombian Constitutional Court, Sentence T-406/92, 1992)

From the point of view of welfare, the social state of law can be defined as one that guarantees minimum standards of wages, food, health, housing and education for all citizens under the idea of law, and not simply as charity. For its part, the democratic constitutional State refers to the intervention of the State in the face of the new values-rights enshrined in the Constitution, such as economic, social and cultural rights (ESCR).

The present study is carried out on the quantitative aspect; that is, on the minimum standards that the State must guarantee to 
improve the standard of living of the associates. The qualitative component is also considered, which is related to the democratic constitutional State and refers to the interventionist activity of the State for the realization of social rights. The two dimensions are analyzed as the two sides of a coin, the quantitative and the qualitative, as components of the social rule of law.

\section{Social RULE OF LAW AND PUBLIC POLICY}

So that the social rule of law is not only a constitutional clause and has materialization and realization in Colombian social life, it is required that the state authorities develop affirmative activities or actions to reach the social goals of the State.

In order to make the social rule of law effective, it is necessary that there is a state public policy that projects not only unsatisfied social needs, but also the mechanisms or means to solve them. Likewise, it must conceive the appropriation of public resources for its execution, in order to then evaluate those public policies through the fulfillment of the projected goals.

In the North American tradition, public policies are understood as the actions of the Government in the search to solve a public problem. In the European conception its definitions are more normative and positive; These consist of an ethic with an emphasis on a series of specific procedures - of a coherent and conscious nature- for public action or goal setting (Matamoros, 2013). In the first case, the actions depend on the Government and their objectives can be truncated when there is a change of government party. In the second, public policy is oriented towards state action without considering the party or government ideology, which allows decisions to meet their objectives.

For the present analysis, public policy is understood as:

State action Guided by the government that, in a coherent, comprehensive, legitimate, systematic and sustainable way seeks to respond to social demands and develop constitutional and legal 
mandates by resorting to different methods of analysis, management models and evaluation criteria, with the participation of the actors involved in the problem and in the search for the solution. (Cuervo, 2010)

Thus, public policy is no longer a unilateral decision of the rulers, but it has to be the product of discussion with populations to determine their needs and solutions. This is what is known today in political science as governance. The mechanism regulated in the constitutional text to guide the action of the State by governments to implement and enforce social demands at the national level is the National Development Plan (PND).

\section{ECONOMIC PLANNING AND THE PUBLIC BUDGet}

The National Development Plan (PND) is the legal-political instrument that allows satisfying the social needs of the Colombian population. In this, it is considered that the rationalization of decisions and social public spending require a process of planning and investment of public resources. Planning in Colombia has evolved in the legal system at the constitutional level; This is how at the beginning of the 20th century there are norms that regulate State intervention and planning.

1. Legislative Act 01 of 1921 enshrined that: “[...] the authorities will inspect industries and professions with regard to morality, security and public health".

2. Legislative Act 01 of 1936, in its article 11, established that: "[...] the State may intervene by means of laws in the exploration of industries and public and private companies in order to rationalize production, distribution and consumption of wealth, or of giving the worker the just protection to which he is entitled".

3. Legislative Act 01 of 1945 attributes to Congress the function of: "[...] setting the plans and programs to which the promotion of the national economy must be submitted and the plans 
and programs of all public works that have to be undertaken and continued".

4. Legislative Act 01 of 1968 created the Plan Commission, whose function was to assume the first debate on the project of the Economic and Social Development plan, a body that was never integrated by political and regional interests. In this regard, the speech delivered by Carlos Lleras Restrepo on November 27, 1965 highlighted the following:

The preparation and execution of development plans, the restoration of fiscal balance, the implementation of the economic-social policy that the country needs require three conditions: unity, persistence, speed. It is not possible to bring them together except under a direction not subject to the continuous struggle of peoplecentered aspirations, foreign to the essence of Government programs. (History of the constitutional reform of 1968, 1969)

The reform introduced an advance in public policy by the Government, but actually the political disputes did not make it possible to apply true planning in Colombia.

Now, the planning model in the constitutional system in force between 1968 and 1991 was summarized by the Constitutional Court in the following terms:

In 1968, the thesis of the unitary national planning policy prevailed, which was born from the exclusive initiative of the government (article 79, paragraph $2 \mathrm{CN} / 86$ ), it was processed in accordance with the rules of article 80 and it was issued by the Congress (article 76 ordinal 4). This unitary tool had repercussions at departmental and municipal levels, since the Congress, through a law that should have been initiated by the Government, established the procedures, modifications and validity of the departmental and municipal plans and programs (Article $189 \mathrm{CN} / 86$ ). However, the system did not work due to the impossibility of applying the procedure of Article 80. (Colombian Constitutional Court, Sentence C-478/92, 1992) 
With the above premises, development plans were presented between 1971 and 1990, as shown in table 1.

Table 1. National Development Plans (1970-1990)

\begin{tabular}{|lll|}
\hline Administration & National Development Plan & \multicolumn{1}{c|}{ President } \\
\hline $1970-1974$ & Plan de las Cuatro Estrategias & Misael Pastrana Borrero \\
$1974-1978$ & Plan para Cerrar la Brecha & Alfonso López Michelsen \\
$1978-1982$ & Plan de Integración Social & Julio César Turbay Ayala \\
$1982-1986$ & Cambio con Equidad & Belisario Betancourt \\
$1986-1990$ & Plan Económico Social & Virgilio Barco Vargas \\
$1990-1994$ & La Revolución Pacífica & César Gaviria Trujillo \\
\hline
\end{tabular}

Source: self-made.

5. The National Constituent Assembly, which adopted the 1991 Constitution, incorporated the issue of regulated planning in the constitutional text (Political Constitution of Colombia, 1991), at the national and territorial level, in relation to the procedures, preparation, approval and execution of development plans through the Organic Law of the Development Plan (Law 152 of 1994).

The PND that was incorporated into the constitutional text is made up of the following components: 1) general part, which indicates the long-term national purposes and objectives, goals and priorities for state action in the medium term, and general strategies and general orientation of the economic, social and environmental policy of the Government; and 2) investment plan, which contains the main programs and projects, as well as the determination of the resources required for their enforcement under the multi-year budgets.

For its part, the National Investment Plan must be approved by means of a law, which will take precedence over other laws and has a temporary validity for each presidential term of government. 
To execute this plan, harmony with the multi-year budgets of each government is required (Political Constitution of Colombia, art. 341, 1991).

The public budget is thus constituted an act of great importance for the country, since the economic policy and the fulfillment of the social purposes of the State depend, to a large extent, on it (Colombian Constitutional Court, Sentence C-1645/00, 2000; Sentence C-258/13, 2013; Sentence C-026/18, 2018). Similarly, the budget is seen as a kind of annual democratic contract on the allocation of scarce resources and the setting of priorities.

Through said contract, the State not only needs a core instrument in the direction of the economic and macroeconomic policy, but it also constitutes the legal tool that quantitatively expresses the fulfillment of the essential purposes of the State and the social policy to achieve them (Political Constitution of Colombia, 1991; Colombian Constitutional Court Sentence C-1065/00, 2000).

During the validity of the 1991 Constitution, the following national development plans have been approved (table 2), the first of them $^{1}$ during the government of Ernesto Samper Pizano.

Table 2. National Development Plans approved after the 1991 constitution

\begin{tabular}{|lll|}
\hline Administration & \multicolumn{1}{c|}{ National Development Plan } & \multicolumn{1}{c|}{ President } \\
\hline $1994-1998$ & El Salto Social & Ernesto Samper Pizano \\
$1998-2002$ & Cambio para Construir la Paz & Andrés Pastrana Arango \\
$2002-2006$ & Hacia un Estado Comunitario & Álvaro Uribe Vélez \\
$2006-2010$ & Estado Comunitario: Desarrollo para Todos & Álvaro Uribe Vélez \\
$2010-2014$ & Prosperidad para Todos & Juan Manuel Santos \\
$2014-2018$ & Todos por un Nuevo País & Juan Manuel Santos \\
$2018-2022$ & Pacto por Colombia, Pacto por la Equidad & Iván Duque Márquez \\
\hline
\end{tabular}

Source: self-made.

1 Law 188 of 1995. National Development and Investments Plan 1995-1998. 
Starting with the 1991 Constitution, the current planning model in Colombia emphasizes the priority of public social spending, the principle of citizen participation and consultation (Alfonso, 2007). The various National Development Plans (PND) presented by the different governments during the legitimacy of the Colombian Constitution (1994-2022) indicated in the previous table include the social component and have not managed to meet the general objectives to embody the social purposes of the Social State of Law.

\section{SOCIAL RIGHTS}

The Colombian Constitution enshrined in the second chapter of the second title the economic, social and cultural rights. There are three views on the incorporation of these rights: 1) those who grant normative nature of full constitutional rights; 2) those who consider that they are programmatic statements that require legal development; 3) an intermediate position sustains that they are constitutional rights that require provision by the state, which implies an economic outlay and, therefore, depend on a political decision.

Nonetheless, this last position, adopted in Colombia, does not imply that the lack of intervention of the legislator to develop the rights (ESCR) does not have binding normative force and can be enforceable before the jurisdiction when the defense of a constitutional principle or a fundamental right is necessary.

The expression social right essentially refers to human rights, such as the right to social security, health, education, housing, water and food (Langford, 2013). The degree of materialization or violation of social rights is an indicator that allows affirming the consolidation or delay of the social state as a constitutional value in Colombia. In this conceptual context we analyze the effectiveness of some of the social rights in Colombia. Not only the constitutional norm is taken into account, but also the state actions or sectorial public policy and the resources assigned in the General Budget of the Nation, compared to indications of the Colombian 
social prevailing circumstances to validate the achievements on the design of the Social State of Law.

\subsection{The Right to heALth}

Health care was guaranteed to all people as a public service in charge of the State at the levels of access to health promotion, protection and recovery services. It is guaranteed as a benefit right included within the Economic, Social and Cultural Rights (Political Constitution of Colombia, 1991, Art. 49). To achieve effectiveness, the Constitutional Court, through judicial decisions, protected the right to health through the thesis of connectedness because it affected other fundamental rights such as life.

After a long period in the defense of the right to health through connectedness, the Constitutional Court determined this right as fundamental (Colombian Constitutional Court, Sentence T-206/08, 2008). The Congress of the Republic, following the criteria of the Constitutional Court, developed the fundamental right to health through the Statutory Law of the Right to Health (SLRH) number $1751 / 15$. Despite the normative changes and the variation in the location of the right to health as fundamental, in the reality of the Colombian population it is found that in order to obtain the protection of the right to health, the jurisdictional guarantee of guardianship is used so that it is not a simple expectation.

This shortcoming in the provision of health services to Colombians, by private and state health promoting entities, is reflected in the lack of infrastructure, medical personnel, supplies, medicines, as well as timely and efficient care for users. Faced with this reality, added to the circumstances of the covid-19 pandemic, which aggravated the efficiency of the health system, it is important to review the main criteria established by the Constitutional Court after the entry into force of the Statutory Law of the Right to Health (SLRH), which continue to be violated and are subject to constitutional protection through tutelage, despite being regulated in standards. 
The current and applicable health criteria are:

1. Universal health coverage, which must be guaranteed to all residents of the country, to the general health and social security system (sGsss) (Colombian Congress, 2011, Law 1438; Colombian Constitutional Court, Sentence T-760/08 , 2008; Sentence T-611/14, 2014; Sentence T-152/19, 2019).

2. Health benefits plan (PBS) that grants system affiliates the guarantee of accessing benefits in all phases of the disease for the effective protection of the right (Law 1757, 2015; Colombian Constitutional Court, Sentence T -117/19, 2019; Sentence $\mathrm{T}-061 / 19,2019)$.

3. Integrity of care so that health services are fully provided regardless of the origin of the disease or health condition of the patient to achieve recovery and social integration (Congress of Colombia, 2015, Law 1751).

4. Supply and payment of specialized therapies for children diagnosed with a physical, sensory or cognitive disorder prescribed by private doctors (Colombian Constitutional Court, Sentence T-563/19, 2019)

5. Transportation, accommodation and food expenses for patients and their companion, as they are considered as elements of effective access (Colombian Congress, 2015, Law 1751) to the right to health (Colombian Constitutional Court, Sentence $\mathrm{T}-259 / 19,2019)$ and are enforceable when, not having them, the materialization of the right is prevented.

6. Moderate fees and copays. Although there is a legal obligation (Congress of the Republic of Colombia, 1993, Law 100), the Constitutional Court has mentioned that such payments cannot become barriers to access health services that users require when it is noticed that patients suffer from a serious illness that prevents them from working, when they are independent workers and do not have a fixed income and when their qualification with the Sisbén (Beneficiary Selection System for Social Programs) has varied over time (Colombian Constitutional Court, Sentence T-081/19, 2019). 
7. The personal caregiver, who is the person who provides physical support so that patients can interact in society and carry out their basic activities to have a dignified life (Colombian Constitutional Court, Sentence T-423/19, 2019).

8. The right to health of migrants, since the only requirement to achieve the effectiveness of the right is to be human. It is an obligation acquired by the Colombian State at the international level (Colombian Constitutional Court, Sentence C-569/19, 2019)

The existence of rules of different levels of hierarchy, constitutional, legal and administrative, as well as jurisprudential rules in the right to health are a chimera. This is reflected in the statistics carried out by the Ombudsman's Office, which in the study on guardianship and rights to health and social security carried out for the year 2019 (table 3), showed the following factual situation regarding the exercise of the guardianship action in Colombia.

Table 3. Registry of guardianships in Colombia (period 1992-2019)

\begin{tabular}{|ccccc|} 
Year & $\begin{array}{c}\mathbf{n}^{\circ} \text { of } \\
\text { Guardianship }\end{array}$ & $\begin{array}{c}\text { Annual } \\
\text { growth (\%) }\end{array}$ & $\begin{array}{c}\mathbf{n}{ }^{\circ} \text { of guardianships } \\
\text { per 10,000 } \\
\text { inhabitants }\end{array}$ & $\begin{array}{c}\text { Annual } \\
\text { growth } \\
\text { (\%) }\end{array}$ \\
\hline 1992 & 10732 & & 3.02 & \\
1993 & 20181 & 88.05 & 5.57 & 84.48 \\
\hline 1994 & 26715 & 32.38 & 7.25 & 30.03 \\
\hline 1995 & 29950 & 12.11 & 7.99 & 10.28 \\
\hline 1996 & 31248 & 4.33 & 8.21 & 2.70 \\
1997 & 33663 & 7.73 & 8.71 & 6.15 \\
1998 & 38248 & 13.62 & 9.76 & 12.03 \\
1999 & 86313 & 125.67 & 21.72 & 122.56 \\
\hline 2000 & 131764 & 52.66 & 32.70 & 50.52 \\
2001 & 133272 & 1.14 & 32.65 & -0.14 \\
\hline 2002 & 143887 & 7.96 & 34.82 & 6.62 \\
2003 & 149439 & 3.86 & 35.71 & 2.57 \\
\hline 2004 & 198125 & 32.58 & 46.76 & 30.95 \\
\hline 2005 & 224270 & 13.20 & 52.29 & 11.82 \\
\hline
\end{tabular}


Table 3. Registry of guardianships in Colombia (period 1992-2019) (continuation)

\begin{tabular}{|ccccc|}
\hline Year & $\begin{array}{c}\mathbf{n}^{\circ}{ }^{\circ} \text { of } \\
\text { Guardianship }\end{array}$ & $\begin{array}{c}\text { Annual } \\
\text { growth (\%) }\end{array}$ & $\begin{array}{c}\mathbf{n}^{\circ} \text { of guardianships } \\
\text { per 10,000 } \\
\text { inhabitants }\end{array}$ & $\begin{array}{c}\text { Annual } \\
\text { growth } \\
(\%)\end{array}$ \\
\hline 2006 & 256166 & 14.22 & 59.02 & 12.86 \\
\hline 2007 & 283637 & 10.72 & 64.57 & 9.41 \\
\hline 2008 & 344468 & 21.45 & 77.50 & 20.01 \\
\hline 2009 & 370640 & 7.60 & 82.41 & 6.34 \\
\hline 2010 & 403380 & 8.83 & 88.64 & 7.56 \\
\hline 2011 & 405359 & 0.49 & 88.04 & -0.68 \\
\hline 2012 & 424400 & 4.70 & 91.13 & 3.51 \\
\hline 2013 & 454500 & 7.09 & 96.45 & 5.84 \\
\hline 2014 & 498240 & 9.62 & 104.54 & 8.38 \\
\hline 2015 & 614520 & 23.34 & 127.49 & 21.95 \\
\hline 2016 & 617071 & 0.42 & 126.58 & -0.71 \\
\hline 2017 & 607499 & -1.55 & 123.25 & -2.64 \\
\hline 2018 & 607308 & -0.03 & 125.84 & 2.11 \\
\hline 2019 & 620257 & 2.10 & 125.57 & -0.22 \\
\hline
\end{tabular}

Source: taken from Ombudsman's Office (2020).

Of the number of guardianships presented for the year 2019, of 620,257 , as verified in the previous table, the right invoked for protection in health matters was 207,368 , as observed in the result below (table 4).

Table 4. Diagnosis in guardianships (2018-2019)

\begin{tabular}{|lcccccc|}
\hline \multirow{2}{*}{ Diagnosis } & \multicolumn{2}{c}{2018} & \multicolumn{2}{c}{2019} & Variation \\
\cline { 2 - 6 } & $\begin{array}{l}\text { Guardian- } \\
\text { ship }\end{array}$ & Part. (\%) & $\begin{array}{c}\text { Guardian- } \\
\text { ship }\end{array}$ & Part. (\%) & (\%) \\
\hline $\begin{array}{l}\text { Tumors (neoplasms) } \\
\begin{array}{l}\text { Diseases of the } \\
\text { genitourinary system }\end{array}\end{array}$ & 2416062 & 11.75 & 26939 & 12.99 & 10.34 \\
\hline
\end{tabular}


Table 4. Diagnosis in guardianships (2018-2019) (continuation)

\begin{tabular}{|c|c|c|c|c|c|}
\hline \multirow{2}{*}{ Diagnosis } & \multicolumn{2}{|c|}{2018} & \multicolumn{2}{|c|}{2019} & \multirow{2}{*}{$\begin{array}{c}\text { Variation } \\
(\%)\end{array}$} \\
\hline & $\begin{array}{l}\text { Guardian- } \\
\text { ship }\end{array}$ & Part. (\%) & $\begin{array}{l}\text { Guardian- } \\
\text { ship }\end{array}$ & Part. (\%) & \\
\hline $\begin{array}{l}\text { Circulatory system } \\
\text { diseases }\end{array}$ & 20224 & 9.74 & 17554 & 8.47 & -13.20 \\
\hline $\begin{array}{l}\text { Diseases of the } \\
\text { musculoskeletal } \\
\text { system and } \\
\text { connective tissue }\end{array}$ & 20288 & 9.77 & 17199 & 8.29 & -15.23 \\
\hline $\begin{array}{l}\text { Endocrine, } \\
\text { nutritional and } \\
\text { metabolic diseases }\end{array}$ & 13396 & 6.45 & 14495 & 6.99 & 8.20 \\
\hline $\begin{array}{l}\text { Trauma, poisoning } \\
\text { and some other } \\
\text { consequences of } \\
\text { external cause }\end{array}$ & 11219 & 5.40 & 14437 & 6.96 & 28.68 \\
\hline $\begin{array}{l}\text { Diseases of the eye } \\
\text { and annexes }\end{array}$ & 12503 & 6.02 & 13096 & 6.32 & 4.74 \\
\hline $\begin{array}{l}\text { Mental and } \\
\text { behavioral disorders }\end{array}$ & 11808 & 5.68 & 12959 & 6.25 & 9.75 \\
\hline $\begin{array}{l}\text { Nervous system } \\
\text { diseases }\end{array}$ & 13939 & 6.71 & 12400 & 5.98 & -11.04 \\
\hline $\begin{array}{l}\text { Symptoms, signs and } \\
\text { abnormal clinical and } \\
\text { laboratory findings } \\
\text { not elsewhere } \\
\text { classified }\end{array}$ & 10191 & 4.91 & 9500 & 4.58 & -6.78 \\
\hline $\begin{array}{l}\text { Digestive system } \\
\text { diseases }\end{array}$ & 10620 & 5.11 & 8403 & 4.05 & -20.87 \\
\hline $\begin{array}{l}\text { Diseases of the } \\
\text { respiratory system }\end{array}$ & 6865 & 3.30 & 7540 & 3.64 & 9.83 \\
\hline $\begin{array}{l}\text { Factors influencing } \\
\text { health status and } \\
\text { contact with health } \\
\text { services }\end{array}$ & 3356 & 1.62 & 6956 & 3.35 & 107.29 \\
\hline
\end{tabular}


Table 4. Diagnosis in guardianships (2018-2019) (continuation)

\begin{tabular}{|c|c|c|c|c|c|}
\hline \multirow[b]{2}{*}{ Diagnosis } & \multicolumn{2}{|c|}{2018} & \multicolumn{2}{|c|}{2019} & \multirow{2}{*}{$\begin{array}{c}\text { Variation } \\
(\%)\end{array}$} \\
\hline & $\begin{array}{l}\text { Guardian- } \\
\text { ship }\end{array}$ & Part. (\%) & $\begin{array}{l}\text { Guardian- } \\
\text { ship }\end{array}$ & Part. (\%) & \\
\hline $\begin{array}{l}\text { Congenital } \\
\text { malformations, } \\
\text { deformities and } \\
\text { chromosomal } \\
\text { abnormalities }\end{array}$ & 5342 & 2.57 & 4496 & 2.17 & -15.84 \\
\hline $\begin{array}{l}\text { Diseases of the skin } \\
\text { and subcutaneous } \\
\text { tissue }\end{array}$ & 2956 & 1.42 & 3252 & 1.57 & 10.01 \\
\hline $\begin{array}{l}\text { Infectious and } \\
\text { parasitic diseases }\end{array}$ & 3082 & 1.48 & 3235 & 1.56 & 4.95 \\
\hline $\begin{array}{l}\text { Diseases of the ear } \\
\text { and mastoid process }\end{array}$ & 4746 & 2.28 & 2834 & 1.37 & -40.28 \\
\hline $\begin{array}{l}\text { Diseases of } \\
\text { the blood and } \\
\text { hematopoietic } \\
\text { organs and other } \\
\text { disorders that affect } \\
\text { the mechanism of } \\
\text { immunity }\end{array}$ & 2091 & 1.01 & 1485 & 0.72 & -28.98 \\
\hline $\begin{array}{l}\text { Certain conditions } \\
\text { originating in the } \\
\text { perinatal period }\end{array}$ & 1019 & 0.49 & 672 & 0.32 & -34.08 \\
\hline $\begin{array}{l}\text { Pregnancy, childbirth } \\
\text { and the puerperium }\end{array}$ & 426 & 0.21 & 381 & 0.18 & -10.57 \\
\hline $\begin{array}{l}\text { Extreme causes } \\
\text { of morbidity and } \\
\text { mortality }\end{array}$ & 358 & 0.17 & 277 & 0.13 & -22.60 \\
\hline $\begin{array}{l}\text { Does not apply/does } \\
\text { not refer }\end{array}$ & 12826 & 6.17 & 10895 & 5.25 & -15.06 \\
\hline Total & 207734 & 100.00 & 207368 & 100.00 & -0.18 \\
\hline
\end{tabular}

Source: taken from Ombudsman's Office (2020).

The diagnoses of the diseases that were subject to constitutional protection for the year 2019 are listed below in table 5 . 


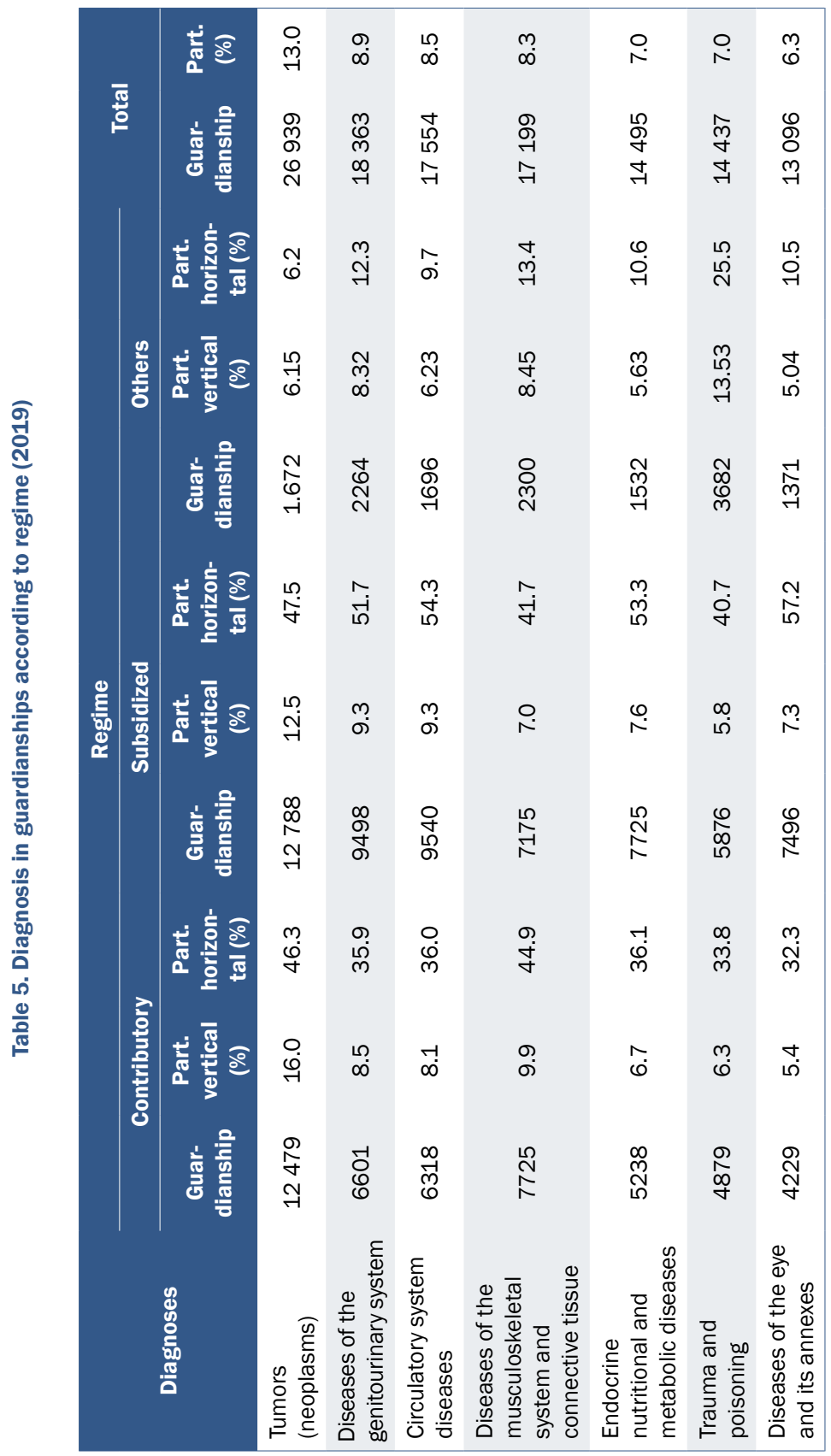




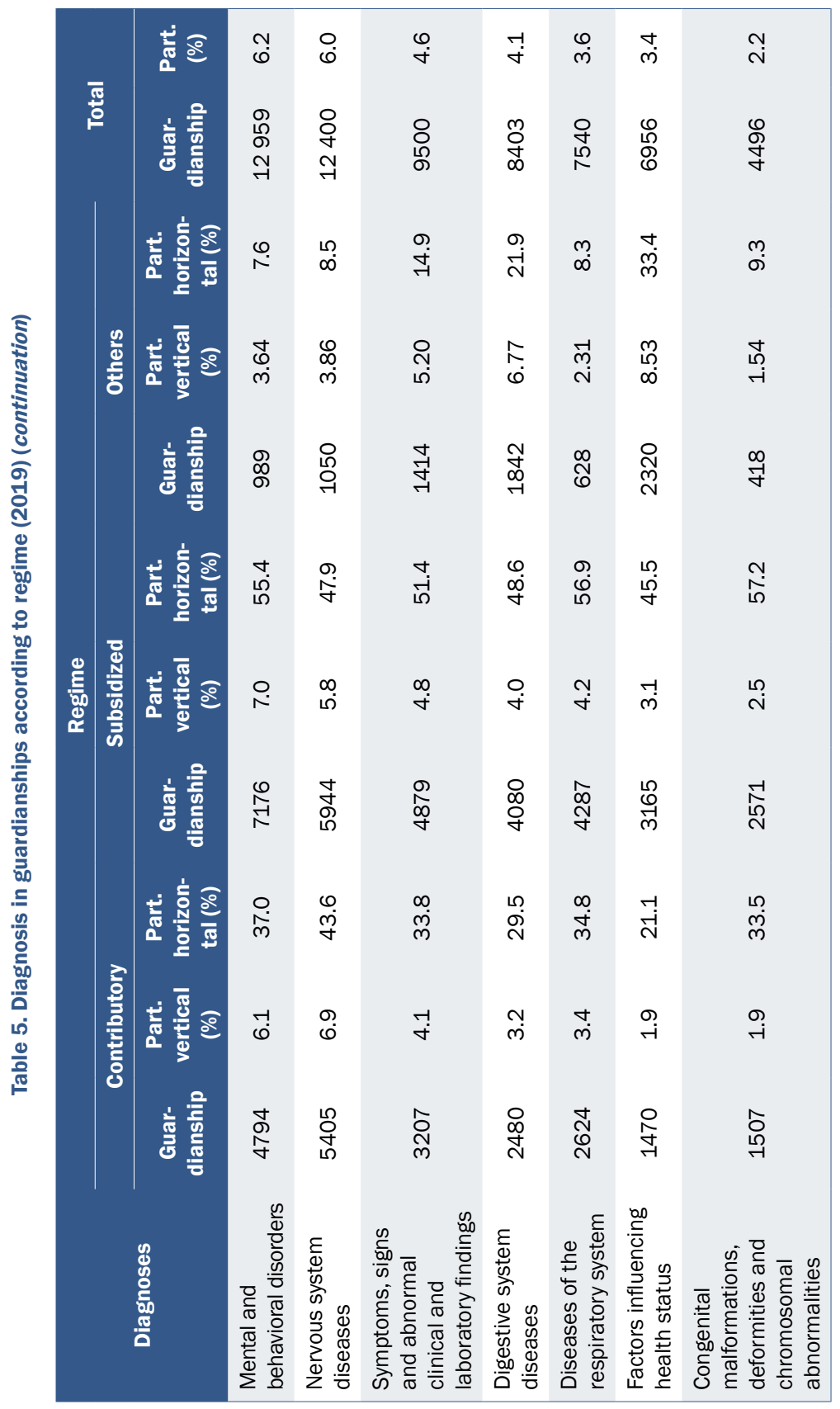




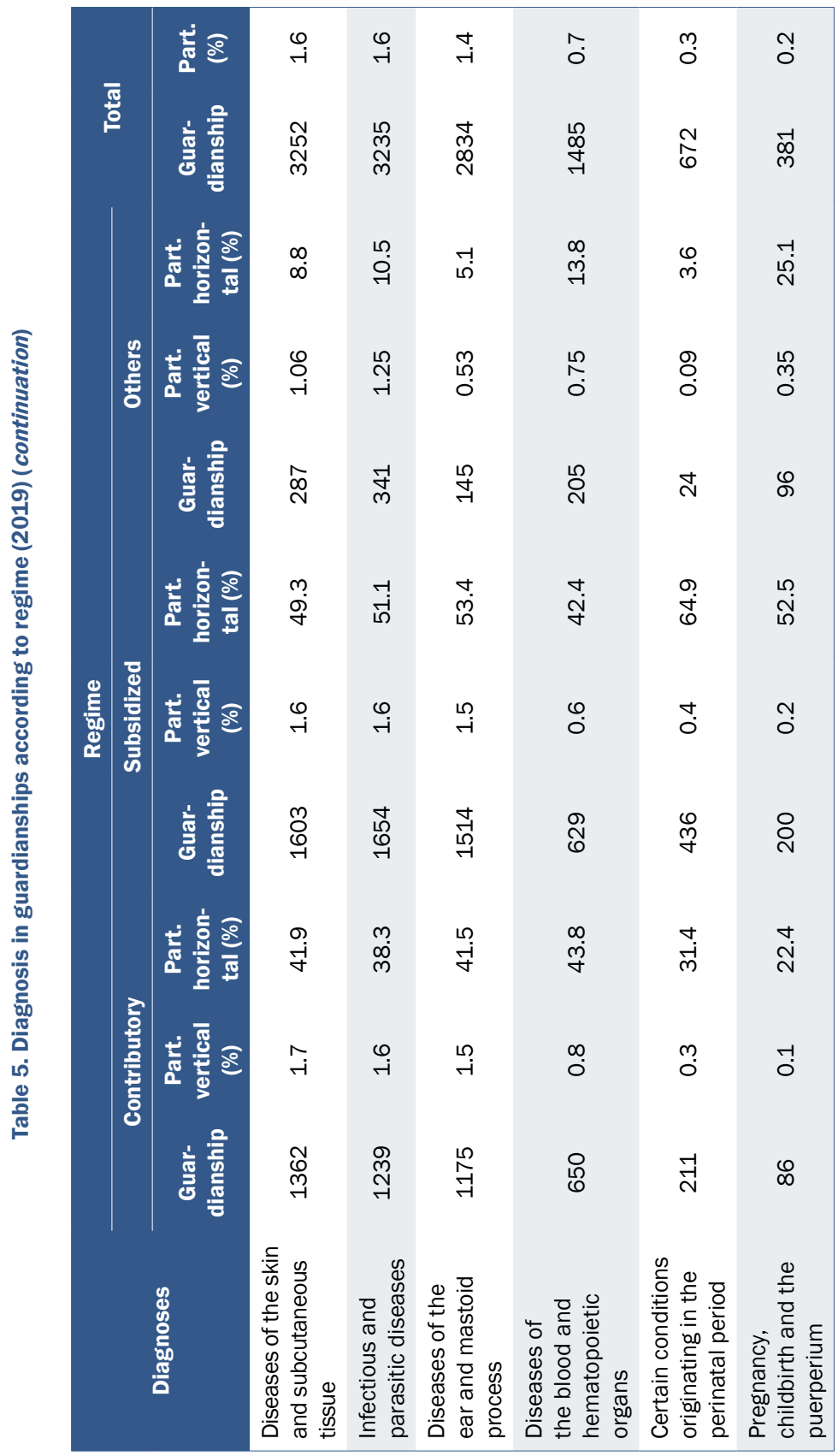




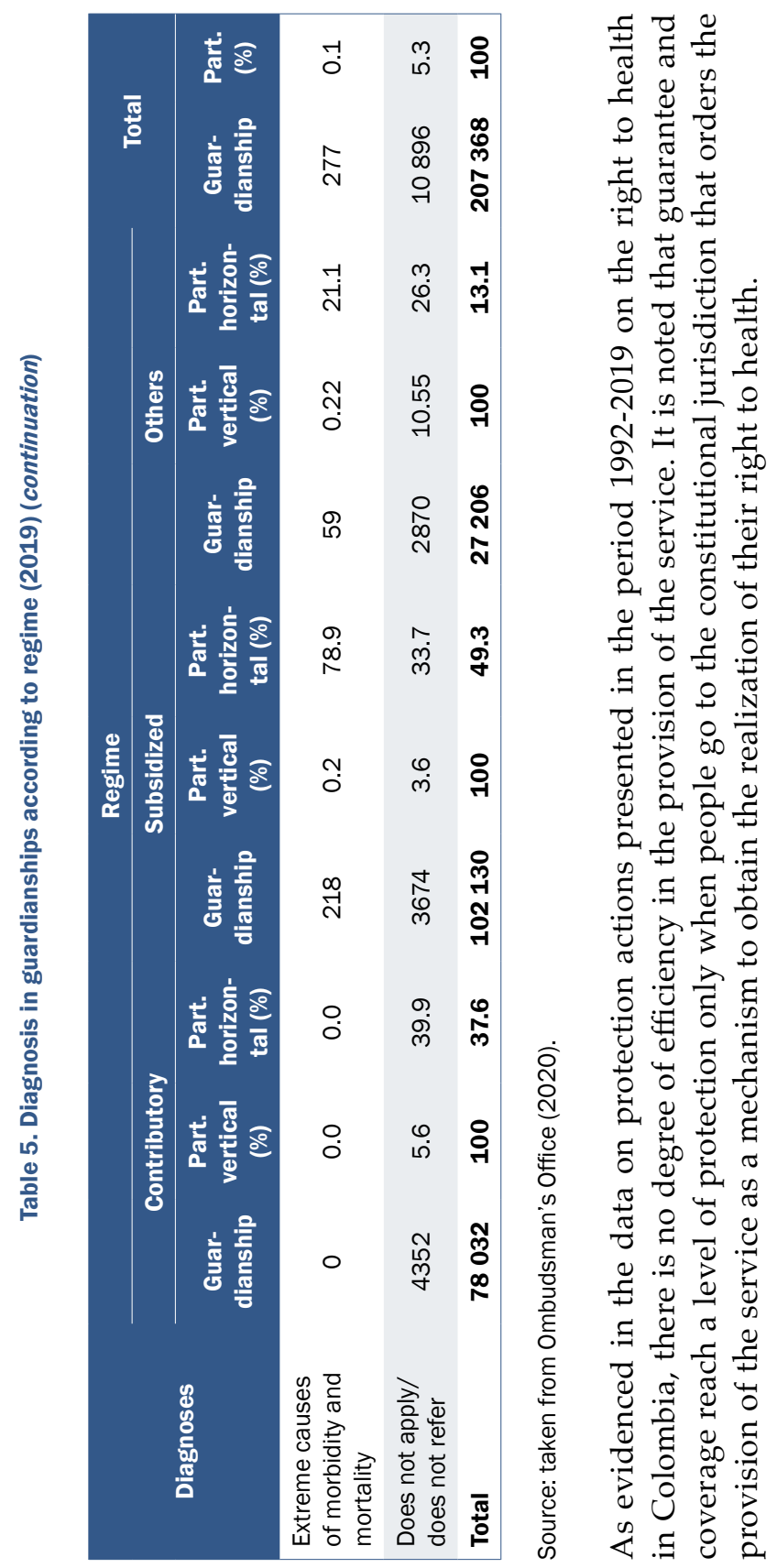




\section{2. The Right to EDUCATION}

The Constitution recognizes the right to education as compulsory and free in state institutions for children between the ages of 5 and 15. It includes at least one year of preschool and nine of basic education (Political Constitution of Colombia, Art. 67. 1991); However, the Constitutional Court has recognized this right by specifying that a child is any person under 18 years of age, which harmonizes the constitutional text with the Convention on the Rights of the Child (CRC) (Colombian Constitutional Court, Sentence T- 323/94, 1994; Sentence T-236/94, 1994).

The jurisprudence of the Constitutional Court has developed the right to education as a duty of the State to guarantee access to educational institutions. According to the data provided by Mauricio Santa María, Carlos Felipe Prada, Katerina Cuellar and Gabriela Paz, the net educational coverage in secondary education went from $62 \%$ to $72 \%$ during the period 2005-2018 and in higher education from $34 \%$ to $52 \%$ (Santa María, 2021).

One of the concerns about education is quality, since Colombia's score in the test results of the Program for International Student Assessment (PISA) for 2018 was 406. This figure was lower than the average for the Organization for Economic Cooperation and Development (OECD) (488) and of the Latin American countries: Chile (438) and Mexico (416); only Peru was surpassed (402).

Among the seventy-nine countries that participated in the tests, Colombia continued to hold the last places, despite the fact that the jurisprudence of the Constitutional Court has reiterated that education:

[...] (i) it is a fundamental and inherent right of individuals and a public service whose provision is an essential purpose of the State; (ii) it is closely linked to the exercise of the right to free choice of profession or trade; (iii) it is a fundamental right of people under 18 years of age; (iv) it is free and compulsory at the basic elementary level; (v) it is a public service so that everyone under the age of 18 has access to at least one year of 
preschool, five years of primary school, and four years of secondary school; (vi) it is made up of four fundamental characteristics that are interrelated: acceptability, adaptability, availability, and accessibility; (vii) public entities of the national and territorial order have the obligation to guarantee adequate coverage of education services and to ensure conditions of access and permanence in the educational system for boys and girls. (Colombian Constitutional Court, Sentence T-207/18, 2018)

On this point of education, there are quantitative advances in access to the educational system. The challenge to overcome is the quality and allocation of resources to meet the coverage and training of teachers for the pedagogical world of the 21st century. Faced with the new socioeconomic reality of the country, other aspects to evaluate are the school dropout caused by covid-19, unemployment and the lack of adaptation to virtuality due to lack of connectivity to develop academic processes.

\subsection{THE RIGHT TO EMPLOYMENT}

Promoting a job placement for people of working age and guaranteeing the population with disabilities the right to work in accordance with their health condition is an essential purpose of the social rule of law to promote the general prosperity of Colombian society. It is a right and a social obligation that enjoys the protection of the State in all its forms (Political Constitution of Colombia, art. 2, 25, 54, 1991).

The constitutional protection of work implies the productive activity of both the employer and the worker; that is, work is a founding principle of the social state of law to build a just order. Thus, one of the purposes of State intervention in the economy is to give full employment to human resources and ensure that all people, particularly those with lower incomes, have effective access to basic goods and services (Constitution Politics of Colombia, art. 334, 1991). The constitutional protection of work and employment in Colombia is increasingly an illusion, according to the following 
unemployment rates (datosmacro.com, 2021a), which deny the social rule of law designed in the 1991 political charter.

As can be seen in table 6, the unemployment rate during the legitimacy of the 1991-2020 Constitution has oscillated between a minimum of $7.6 \%$ (1994) and a maximum of $15.9 \%$ (2020). This is a clear indicator of the lack of a public policy of the State that promotes employment and the quality of life of Colombians through the productive activities in the country.

Table 6. Unemployment in Colombia 1991-2020

\begin{tabular}{|cccccc|}
\hline Year & $\%$ & Year & $\%$ & Year & $\%$ \\
\hline 1991 & 9.8 & 2001 & 17 & 2011 & 10.8 \\
1992 & 9.2 & 2002 & 15.7 & 2012 & 10.48 \\
1993 & 7.9 & 2003 & 14.1 & 2013 & 9.6 \\
1994 & 7.6 & 2004 & 13.6 & 2014 & 9.1 \\
1995 & 8.7 & 2005 & 11.7 & 2015 & 8.9 \\
1996 & 11.9 & 2006 & 12 & 2016 & 9.2 \\
1997 & 12.1 & 2007 & 11.1 & 2017 & 9.4 \\
1998 & 15.7 & 2008 & 11.3 & 2018 & 9.7 \\
1999 & 18.1 & 2009 & 12 & 2019 & 10.5 \\
2020 & 19.7 & 2010 & 11.8 & 2020 & 15.9 \\
\hline
\end{tabular}

Source: adapted from DANE - National Administrative Department of Statistics (2020).

\subsection{RIGHT TO DRINKING WATER}

The provision of public services is a social duty of the State, as well as ensuring their efficient provision to all inhabitants of the national territory (Political Constitution of Colombia, 1991). Among the social purposes of the State is the solution to the unsatisfied needs of drinking water, to guarantee the general well-being and quality of life of populations (Political Constitution of Colombia, 1991). 
The Colombian constitutional charter of 1991 does not expressly establish access to drinking water as a fundamental right. At present it has been recognized as such because it is an elementary public resource for life, health and essential to realize other rights (Colombian Constitutional Court, Sentence T-118, 2018).

The previous configuration of the right to water incorporates observation No. 15/02 of the United Nations (UN) in the interpretation of ESCR, which considers them as fundamental rights to benefit, and obliges States and, in some cases, individuals to carry out the actions that lead to actual compliance (Vargas, 2018). The minimum essential requirements for access to drinking water in any circumstance recognized by the international standards of ESCR were incorporated by the jurisprudence of the Constitutional Court, such as: 1) availability; 2) quality and 3) accessibility.

Availability refers to the continuous and sufficient supply to each person for personal and domestic uses; Quality is understood as safe water for personal and domestic use, it must not contain chemical or radioactive substances that affect health and accessibility. Water facilities and services must be accessible to all, without any discrimination throughout the Colombian territory. This interpretation and jurisprudential rule on the fundamental right to drinking water is a conceptual advance, since the broad national geography, both in urban and rural areas, is increasingly distant from the norms and rulings of the Constitutional Court, due to the lack of coverage or expansion of public service networks, particularly drinking water and environmental sanitation.

On the other hand, we find that in some regions there is a deficient supply of drinking water service and poor water quality; Furthermore, there is no coverage for the entire population. Although the coverage of the aqueduct and sewerage service has been increased in recent years, the quality of the water supplied has not improved substantially, according to the evaluation of the Superintendency of Public Services (Economic Commission for Latin America and the Caribbean [ECLAC], s. f.). The failure to comply with the social obligation of the State in matters of environmental sanitation and drinking water at the national 
level and of the territorial entities is evident, since it does not include these matters in public social spending within their respective development plans and budgets, which should prevail on another assignment, because it is a constitutional mandate (Political Constitution of Colombia, art. 360. 1991)

\subsection{Right to HOUSING}

The Colombian Constitution recognizes the right to decent housing (Political Constitution of Colombia, art. 54, 1991), but there is no guarantee of direct constitutional protection and it can only be claimed by Colombian nationals. For the UN Committee on ESCR, having a home means:

[...] have a place where people can isolate if they wish, space, security, adequate lighting and ventilation, as well as a basic infrastructure and an adequate situation in relation to work and basic services, all these conditions at a reasonable cost. (International Network for Economic, Social and Cultural Rights, 1991)

The Colombian Constitutional Court determined this guarantee of decent housing as an autonomous fundamental right (Colombian Constitutional Court, Sentence T-986A/12, 2012); and its materialization does not only imply the possibility of acquiring a property for their room but, in turn, that their access is real and stable for their effective enjoyment, that it is constituted in a suitable place for the person and their family so that it can be develop in a condition of dignity (Colombian Constitutional Court, Sentence T-420/18, 2018). By constitutional mandate, the State has the task of establishing the necessary conditions to make this right effective and to promote social interest housing plans, appropriate longterm financing systems and community plans for the execution of these housing programs.

The right to decent housing imposes on the competent authorities the duty to provide appropriate information and assistance with the procedures and compliance with the necessary requirements 
to make housing subsidies effective (Colombian Constitutional Court, Sentence T-602/03, 2003). The Court has protected the right to housing of people in a situation of vulnerability from state actions that seriously affect the minimum conditions of a dignified life of these people, even if they are in accordance with the law. In other words, the right to housing is subject to constitutional protection in cases of violation of other fundamental rights.

According to the figures of the April 2020 report of the Population and Housing Census carried out by the National Planning Department (PND), the National Administrative Department of Statistics (DANE) and the UN, about 18.2 million Colombians live in housing deficit, which is equivalent to $36.59 \%$ of the current population in our country (Urrego Jiménez, 2020).

\section{ECONOMIC GROWTH AND POVERTY}

An indicator of Colombian economic growth for the period 19912020 is the rate of Gross Domestic Product (GDP), which represents the final result of the productive activity of the production units, resident in the country. This indicator shows the deterioration or quality of life of Colombians for the period 1991-2020 (table 7) (datosmacro.com, 2021b).

The highest growth rate for the analyzed period was 6.9 for 2011 and the lowest corresponded to -6.5 for 2020 . These indicators show a deterioration in the quality of life of Colombians, contrary to one of the social purposes of the State, which is general prosperity.

For the variable economic growth crossed with unemployment rate, it was found that the year with the highest productive growth was $2011(6.9 \%)$, paradoxically an unemployment rate of $10.8 \%$; and in 2020 a drop in productivity of $-6.8 \%$, the unemployment rate was $15.9 \%$. The productivity/employment relationship reflects that there is no correlation between economic growth and job creation. In other words, the State has not fulfilled the constitutional purpose of achieving an improvement in 
the quality of life of its inhabitants, the equitable distribution of opportunities and the benefits of development, which is one of the goals of the social rule of law.

Table 7. Gross Domestic Product (GDP) 1991-2020 Colombia

\begin{tabular}{|cccccc|}
\hline Year & \% GDP & Year & \% GDP & Year & $\%$ GDP \\
\hline 1991 & 2.8 & 2001 & 1.7 & 2011 & 6.9 \\
1992 & 4.3 & 2002 & 2.5 & 2012 & 3.9 \\
1993 & 5.3 & 2003 & 3.9 & 2013 & 5.1 \\
1994 & 5.6 & 2004 & 5.3 & 2014 & 4.5 \\
1995 & 5.3 & 2005 & 4.7 & 2015 & 3 \\
1996 & 1.6 & 2006 & 6.7 & 2016 & 2.1 \\
1997 & 3.2 & 2007 & 6.7 & 2017 & 1.4 \\
1998 & 0.6 & 2008 & 3.3 & 2018 & 2.5 \\
1999 & -5.2 & 2009 & 1.1 & 2019 & 3.3 \\
2000 & 2.6 & 2010 & 4.5 & 2020 & -6.8 \\
\hline
\end{tabular}

Source: adapted from DANE (2020).

The Gini index —which measures the distribution of income among individuals or households within an economy- is far from an equitable distribution. Colombia is the second country with the highest level of inequality in Latin America based on the Gini coefficient (0.538), surpassed only by Haiti (0.608). There is an inequality gap with Uruguay of 0.419 , the country with the lowest inequality in the region ${ }^{2}$.

For 2019, poverty in Colombia concluded with a rate of $37.5 \%$ (Amaya, 2020), and according to Jairo Niño, a researcher at $\mathrm{Fe}$ -

2 The figures for Colombia correspond to 2014 and were taken from DANE. For the other Latin American countries, the World Bank's Poverty and Inequality Database was consulted: http://databank.bancomundial.org/data/reports.aspx?source=base-de-datos-sobre-pobreza-y-desigualdad\# 
desarrollo (Foundation for Higher Education and Development), there was an increase in the level between $47 \%$ and $49 \%$ due to the effects of the measures. adopted by the pandemic by covid- 19 . In general terms, poverty is understood as the lack or material insufficiencies of what is necessary to satisfy one or several needs of the human being (Moreno, 2013). That is to say, at present, the constitutional norms that order the authorities to materialize the social rule of law are a utopia to guarantee the satisfaction of the basic needs of inhabitants in Colombian territory.

\section{Conclusions}

The transformation of the design of the Colombian State is notable with the approval of the 1991 Constitution, which consolidates the paradigm of the social State of law, which replaces the vision of the State of law conformed by the Constitution of 1886 . The social purposes of the State of Right must be reflected in better conditions and quality of life for Colombians.

Despite the fact that one of the contributions of the new constitutional charter was the incorporation of the so-called second and third generation rights, such as economic, social and cultural rights (ESCR), there is no realization of these rights in real terms. It is necessary for the State to adopt public policies to carry out affirmative actions to achieve the effectiveness of social rights which, in comparative law, are: health, education and housing. In our country, these rights have been legally configured by the Constitutional Court as fundamental rights, in order to be protected through the procedural guarantee of guardianship and not only as benefit rights; due to their deficiency, they require a political decision and the allocation of resources for their implementation.

With the indicators observed during the legitimacy of the Constitution from 1991 to 2020, we find a reflection of the complex Colombian prevailing circumstances, which allows us to conclude the ineffectiveness of the social rule of law. In other words, 
there is a gap between the normative framework that indicates the political organization in Colombia as a social State and the realization of social rights, such as health, housing, education and work.

The situation facing Colombian society is the product of the lack of a public policy on the part of the different governments, despite the fact that they formally comply with the requirement of preparing the National Development Plan (PND) and incorporating the general objectives of the concern for the satisfaction of social needs. Multi-year budgets are not in line to cover them and the necessary resources are not allocated for this purpose.

The above circumstances allow us to conclude that, despite the normative existence of the social rule of law, in the reality of Colombian society the different components are not manifested to fulfill the purposes of this model. Consequently, we can affirm that the model of the social rule of law in Colombia is a fallacy that must be fought in order to build - in real terms- a society in accordance with the purposes of the Social Rule of Law.

To realize the social rule of law, it is necessary to make effective the rights to health, housing, education, work, etc. For which a public policy of the State that in the medium and long term is executed regardless of the ideology or government party. The achievement of its objectives is obtained through the allocation of public resources for their implementation in the respective budgets that implement the public policies designed in the National Development Plans, in order to close that gap between the regulatory framework and reality.

At present, social rights for some sectors of Colombian population have been guaranteed as a consequence of jurisdictional activity. This through the constitutional protection and the mandates to the organs of power, so that they adopt the corresponding actions for the effective protection of rights.

It is essential to allocate resources to implement and execute public policies that would improve the quality of life of Colombians, as well as to ensure their execution and subsequent evaluation, 
to verify compliance with the social purposes of the State. This task is carried out from the discipline of political science, which is responsible for assessing the result of public policies designed to meet the projected goals to satisfy unmet needs and achieve the best quality of life for Colombians.

\section{RefEREnCES}

Alfonso, J. L. (2007). Presupuesto: Una aproximación desde la planeación y el gasto público. Universidad del Rosario.

Amaya, J. S. (2020, 19 de octubre). La pobreza en Colombia va a alcanzar un nivel de entre $47 \%$ y 4 9\% por la pandemia del covid. La República. http: / / bit. ly/390MHJT

Banco Mundial. (2021). Indicadores: Pobreza. http:/ / bit.ly/3r7ycKu

Comisión Económica para América Latina y el Caribe (Cepal). (s. f.). Agua para el Siglo XXI para América del Sur. De la visión a la acción. Informe: Colombia. https: / / bit.ly/312Kgm0

Congreso de la República de Colombia. (1936, 5 de agosto). Acto Legislativo 1 de 1936. Reformatorio de la Constitución. Diario oficial 23263.

Congreso de la República de Colombia. (1993, 23 de diciembre). Ley 100 de 1993. Por la cual se crea el sistema de seguridad social integral y se dictan otras disposiciones. Diario oficial: 41148.

Congreso de la República de Colombia. (1994, 19 de julio). Ley 152 de 1994. Por la cual se establece la Ley Orgánica del Plan de Desarrollo. Diario oficial 41450.

Congreso de la República de Colombia. (2011, 19 de enero). Ley 1438 de 2011. Por medio de la cual se reforma el Sistema General de Seguridad Social en Salud y se dictan otras disposiciones. Diario oficial: 47957.

Congreso de la República de Colombia. (2015, 16 de febrero). Ley Estatutaria 1751 de 2015. Por medio de la cual se regula el derecho fundamental a la salud y se dictan otras disposiciones. Diario oficial 49427.

Congreso de la República de Colombia. (2015, 6 de julio). Ley Estatutaria 1757 de 2015. Por la cual se dictan disposiciones en materia de promoción y protección del derecho a la participación democrática. Diario oficial 49565.

Constitución Política de Colombia. (1991). Gaceta Constitucional n. ${ }^{\circ}$ 116. http:// bit.ly / 2NA2BRg

Corte Constitucional de Colombia. (1992, 5 de junio). Sentencia T-406/92 (Ciro Angarita Barón, M. P.).

Corte Constitucional de Colombia. (1992, 6 de agosto). Sentencia C-478/92 (Eduardo Cifuentes Muñoz, M. P.).

Corte Constitucional de Colombia. (1993, 29 de julio). Sentencia C-295/ 93 (Carlos Gaviria Díaz, M. P.). 
Corte Constitucional de Colombia. (1994, 14 de julio). Sentencia T-323/94 (Eduardo Cifuentes Muñoz, M. P.).

Corte Constitucional de Colombia. (1994, 17 de mayo). Sentencia T-236/ 94 (Antonio Barrera Carbonell, M. P.).

Corte Constitucional de Colombia. (2000, 16 de agosto). Sentencia C-1065/00 (Alejandro Martínez Caballero, M. P.).

Corte Constitucional de Colombia. (2000, 29 de noviembre). Sentencia C-1645/00 (Carlos Gaviria Díaz, M. S.).

Corte Constitucional de Colombia. (2003, 23 de julio). Sentencia T-602/03 (Jaime Araújo Rentería, M. P.).

Corte Constitucional de Colombia. (2008, 28 de febrero). Sentencia T-206/ 08 (Clara Inés Vargas Hernández, M. P.).

Corte Constitucional de Colombia. (2008, 31 de julio). Sentencia T-760/ 08 (Manuel José Cepeda Espinosa, M. P.).

Corte Constitucional de Colombia. (2012, 22 de noviembre). Sentencia T-986A/12 (Luis Ernesto Vargas Silva, M. P.).

Corte Constitucional de Colombia. (2013, 7 de mayo). Sentencia C-258/13 (Jorge Ignacio Pretelt Chaljub, M. P.).

Corte Constitucional de Colombia. (2014, 25 de agosto). Sentencia T-611 / 14 (Jorge Iván Palacio Haberle, M. P.).

Corte Constitucional de Colombia. (2018, 11 de abril). Sentencia C-026/18 (José Fernando Reyes Cuartas, M. P.).

Corte Constitucional de Colombia. (2018, 11 de octubre). Sentencia T-420/18 (Antonio José Lizarazo Ocampo, M. S.).

Corte Constitucional de Colombia. (2018, 30 de mayo). Sentencia T-207 / 18 (Gloria Stella Ortiz Delgado, M. P.).

Corte Constitucional de Colombia. (2018, 6 de abril). Sentencia T-118/18 (Cristina Pardo Schlesinger, M. P.).

Corte Constitucional de Colombia. (2019, 12 de septiembre). Sentencia T-423/19 (Gloria Stella Ortiz Delgado, M. P.).

Corte Constitucional de Colombia. (2019, 14 de febrero). Sentencia T-061/19 (Alejandro Linares Cantillo, M. P.).

Corte Constitucional de Colombia. (2019, 16 de febrero). Sentencia T-081/19 (Luis Guillermo Guerrero Pérez, M. P.).

Corte Constitucional de Colombia. (2019, 18 de marzo). Sentencia T-117/ 19 (Cristina Pardo Schlesinger, M. P.).

Corte Constitucional de Colombia. (2019, 2 de abril). Sentencia T-152/19 (José Fernando Reyes Cuartas, M. P.).

Corte Constitucional de Colombia. (2019, 20 de noviembre). Sentencia T-563/19 (Luis Guillermo Guerrero Pérez, M. P.).

Corte Constitucional de Colombia. (2019, 27 de noviembre). Sentencia C-569/19 (Alejandro Linares Cantillo, M. P.).

Corte Constitucional de Colombia. (2019, 6 de junio). Sentencia T-259/19 (Antonio José Lizarazo Ocampo, M. P.). 
Cuervo, J. I. (2010). Las políticas públicas y el marco normativo colombiano. En: Boletín política pública hoy. No. 3. Abril 2010. (5-8) Departamento Nacional de Planeación (DPN). https: / / bit.ly/3cWg9lo

datosmacro.com. (2021a). http:/ / bit.ly/314bbgZ

datosmacro.com. (2021b). http:/ / bit.ly/3lE7Mir

Defensoría del Pueblo. (2020). La Tutela y los Derechos a la Salud y la Seguridad Social 2019. https: / / bit.ly/3eZBqxn

Häberle, P., Valadés Galeana, J. D. y Fix Fierro, H. (2007). El Estado constitucional: Proceso constituyente, derechos fundamentales, dignidad humana, libertad cultural, trabajo y propiedad, interpretación y comparación de textos constitucionales, influencias en América, reforma de la Constitución, Estado constitucional comparativo. Editorial Astrea de Alfredo y Ricardo Depalma.

Langford, M. (ed.). (2013). Teoría y jurisprudencia de los derechos sociales: Tendencias emergentes en el derecho internacional comparado. Siglo del Hombre Editores: Universidad de Los Andes.

Matamoros, G. O. (2013). Manual de análisis y diseño de políticas públicas. En Books (Vol. 1). Universidad Externado de Colombia, Facultad de Finanzas, Gobierno y Relaciones Internacionales. https: / bit.ly/3s2Nh1k

Moreno López, W. (2013). Actuales políticas de lucha contra la pobreza en América Latina: Protección social de mercado. Corporación Universitaria Republicana.

Motta Vargas, R. (2018). El derecho de la gestión comunitaria del agua en Colombia para garantizar el acceso al agua potable. Misión Jurídica, 11(15), 317-330.

Presidencia de la República de Colombia. (1969). Historia de la reforma constitucional de 1968. Imprenta Nacional.

Red Internacional para los Derechos Económicos, Sociales y Culturales (1991). CESCR Observación general $N^{\circ} 4$ (General Comments) https: / / bit.ly/3qZTutG

Santa María, M. (2020, 18 de marzo). Educación en Colombia: Avances en cobertura y desafíos en calidad. La República. http: / / bit.ly/392CCMB

Tascón, T. E. (1944). Derecho Constitucional Colombiano, comentarios a la constitución nacional. Editorial La Gran Colombia.

Urrego Jiménez, A. (19 de abril de 2020). Más de un tercio del país están en déficit habitacional. Portafolio. http: / / bit.ly /3cXeAnD

Vargas, R. M. (2018). El derecho de la gestión comunitaria del agua en Colombia para garantizar el acceso al agua potable. Misión Jurídica, 11(15), 319. 